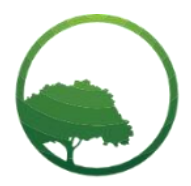

Research in Business \& Social Science

IJRBS VOL 10 NO 7 ISSN: 2147-4478

\title{
Customers' behavioral intention on mobile banking services in Indonesia
}

\author{
(iD) Edwin Bustami (a) (iD) Sihol Situngkir (b) (iD) Syahmardi Yacob ${ }^{(c) *(1 D)}$ Ade Octavia $^{(d c) *}$ \\ (a) Ph.D., Program in Economics, Faculty of Economics and Business, Universitas Jambi, Indonesi \\ (b) Professor, Faculty of Economics and Business, Universitas Jambi, Kampus Unja Mendalo Darat, Jambi, Indonesia \\ (c) Associate Professor, Faculty of Economics and Business, Universitas Jambi, Kampus Unja Mendalo Darat, Jambi, Indonesia
}

\begin{tabular}{l} 
A R T I C L E I N F O \\
\hline Article history: \\
Received 24 September 2021 \\
Received in rev. form 24 Oct. 2021 \\
Accepted 27 October 2021 \\
Keywords: \\
Behavioral Intention, Mobile Banking \\
Services, Culture, Enjoyment \\
JEL Classification: \\
M30
\end{tabular}

\begin{abstract}
A B S T R A C T
This study examines the effects of knowledge, trust, enjoyment, risk, and culture on perceived ease of use, attitudes, perceived usefulness, and behavioral intention for choosing Jambi mobile banking services. Survey and verification methods were used with a sample of 400 units. Furthermore, this study used an accidental sampling method and analyzed data through Path Analysis. Findings of the study demonstrated that knowledge, enjoyment, and risk directly and significantly affect Indonesian customer attitudes, while trust does not influence perceived ease of use, perceived usefulness, and behavioral intention. Moreover, risk and culture directly and significantly affect perceived ease of use and perceived usefulness.
\end{abstract}

(C) 2021 by the authors. Licensee SSBFNET, Istanbul, Turkey. This article is an open access article distributed under the terms and conditions of the Creative Commons Attribution (CC BY) license (http://creativecommons.org/licenses/by/4.0/).

\section{Introduction}

Behavioral intention is an important aspect that needs to be considered in the banking sector. The customer intends to return, give a positive word of mouth, stay longer or make more banking transactions, though this is challenging for the banking service providers.

Service providers must ensure consumers have positive behavioral intentions towards the company. The intention to behave positively reciprocates consumer satisfaction with producers. Knowing consumers' behavioral intentions enables producers to position themselves and improve performance. However, customer satisfaction is not the only marketing goal. Companies need to provide a holistic experience to capture consumers' impressions after using or buying products or services to achieve customer satisfaction. Customers feel many benefits of M-banking facilities, such as efficiency. In this case, M-banking encourages customers to adopt self-service technology, allowing additional benefits, such as cost savings and cross-selling activities (Sharma \& Govindaluri, 2014). Moreover, M-banking services enhance effectiveness through time management. One latest marvel of mobile technology (Shaikh \& Karjaluoto, 2015) and innovation in the financial sector is the pure mobility to service consumption (Mishra \& Bisht, 2013). The security in transactions tremendously impacts banking customers. The theory by Davis et al. (1989) on the technology acceptance model stated that consumer interest in using technology in decision-making focuses on their attitude by relating it to enjoyment. Munir et al. (2013) showed that the influence of knowledge on attitudes, Perceived Ease of Use, and intentions are positive and significant, in line with Roslina (2009). However, other results showed no effect of knowledge on attitudes and Perceived Usefulness (Munir et al., 2013). This contradicts Park \& Kim (2008), which found that consumers' knowledge affects the perceived usefulness of a product. Munir et al. (2013) showed that the effect of trust on attitudes, perceived ease of use, perceived usefulness, and intentions is positive and significant in line with (Salo \& Karjaluoto, 2007). However, to provide further evidence, these results should be re-examined using other variables to determine the direct or indirect effect. Enjoyment determines attitudes, perceived ease of use, usefulness, and customer intentions in using mobile banking (Munir et al., 2013). This finding was supported

* Corresponding author. ORCID ID: 0000-0002-6827-277X

(C) 2021 by the authors. Hosting by SSBFNET. Peer review under responsibility of Center for Strategic Studies in Business and Finance. https://doi.org/10.20525/ijrbs.v10i7.1403 
by Bruner \& Kumar (2005). However, the findings of several experts should be re-examined to determine the direct or indirect effect using cultural variables to provide further evidence.

Risk is another determinant of attitude, though these findings contradict Munir et al. (2013). The study stated that risk positively affects attitudes, contradicting Teo \& Liu (2007). Risk negatively and significantly affects enjoyment, perceived usefulness, and intention (Munir et al., 2013). These results are consistent with Li \& Huang (2009). Therefore, the gap should be re-examined using cultural variables to determine the intention to use mobile banking. Debjani (2017) stated that attitude does not support customer intentions in adopting m-banking. This result contradicts Munir et al. (2013), which showed that the perceived ease of use and usefulness variables positively and significantly affect the intention to use mobile banking. The finding supports Hernandez \& Mazzon (2007), which found that attitude positively and significantly influences customer intention.

\section{Literature Review}

\section{Theoretical and Conceptual Background}

\section{Behavioral Intention (B.I.)}

Ajzen \& Fishbein (1975) proposed a theory of behavior formation built by the reciprocal relationship between trust, attitudes, and Behavioral Intentions. Trust is the information a person has about an object, while attitude is how they think, view, or evaluate it. In contrast, behavioral intention is an individual's intent to behave. Previous studies showed that the intention to act positively impacts a person's behavior (Kuo et al., 2009). Also, approximately $19 \%$ to $38 \%$ of behavior could be interpreted by B.I. (Armitage et al., 2001).

\section{Knowledge}

Mowen \& Minor (2002) defined consumer knowledge as the experience and information about a particular product or service a person has. Furthermore, Miniard et al. (2005) stated that consumer knowledge could be interpreted as information stored within memory. Kotler \& Kemmer (2012) defined knowledge as an individual or group action from which a lesson is drawn. A consumer would be significantly influenced by their buying interest by the knowledge of a product. In line with this, Roslina (2009) stated that the level of consumer product knowledge affects intentions to buy a product. Therefore, the complete information relevant to consumers' enjoyment in the marketplace is called consumer knowledge".

\section{Trust}

Relationships of trust are widely recognized as significant factors for various people or things (Shaikh et al., 2015). Yudiarti et al. (2018) stated the reason to trust a successful company or organization in line with (Salo et al., 2007). Trust benefits companies by reducing transaction costs, increasing flexibility and efficiency, and helping design more accurate marketing plans or strategies (Karjaluoto et al., 2008). In general, trust relies on integrity, ability, or character that significantly impacts consumers' willingness to transact online because it helps them with uncertainty.

\section{Perceived Enjoyment}

Enjoyment is the degree to which the use of a system is personally enjoyable. The effect of perceived enjoyment on the enjoyment of use is vital for users with direct experience of the system. Specifically, it affects the enjoyment of use and perceived usefulness. Moreover, Sun et al. (2006) stated that perceived enjoyment could trigger enjoyment of use, especially when it is a determinant of intention to use a system.

\section{Risk Perception}

Previous studies stated that risk perception essentially influences online consumer behavior (Schlosser et al. 2006). Online economic transactions present various risks for consumers. In the online environment, crimes could be committed at high speed and without physical contact (Lee et al., 2006). When an unauthorized person accesses one's mobile banking, some financial information may leak, potentially resulting in financial loss. Mobile banking is mainly characterized by the financial and security risks associated with possible loss due to deficiencies in the operating system (Littler, \& Melanthiou, 2006).

\section{Culture}

Dwiastuti et al. (2012) defined culture as the trust, values, and habits a person learns in using an item or service. Trusts, values, and habits arise when people interact, relate, and influence behavior. Cultural elements, including values, norms, habits, prohibition, myths, and symbols, affect product and service consumption.

\section{Attitude}

Miniard et al. (2005) identified five dimensions of attitude, including direction (valence), extremity, resistance, persistence, and confidence level, related to how specific a person is regarding their attitude. 


\section{Perceived Ease of Use (PEOU)}

PEOU is the degree to which a person believes that using a particular system would be effortless. The difficulty in using a system sometimes overrides the resulting benefits, explaining the effect of PEOU on the system's P.U. This is because an easy-to-use system is more valuable and vice versa (Park et al., 2009). PEOU directly influences Behavioral Intention to use a system. The influence of PEOU and P.U. in different environments and organizations shows that these factors are valid, reliable, and influence their use.

\section{Perceived Usefulness (P.U.).}

P.U. is the perceived usefulness of a system visible to the user. It states that the user continues to utilize the system until they find it no longer helpful. Davis et al. (1989) defined P.U. as the degree to which a person believes that using a particular system improves performance. It is a critical factor influencing the Behavioral Intention to use a system. Most studies highly emphasize this aspect when examining the factors leading to I.T. adoption (Park et al., 2009).

\section{Research Framework}

Industry 4.0 era marked by a touch of technology on all sides, people's understanding of the banking world and their expectations of the technology used in banking transactions are conveniences, security, comfort, and speed in carrying out all banking transactions (Hacioglu \& Sevgilioglu, 2019). In this study, the theory of buyer behavior is used and divided into three dimensions, namely cognition (thoughts), affection (emotions), and conation (activity). Meanwhile, the theory of reasoned action model includes three parts: behavioral intention, attitude, and subjective norm. The theory explains that consumer behavior in terms of their attitudes towards behavior and their views of others. Whereas in the theory of technology acceptance model, it is stated that consumer interest in using technology for consumer decision-making focuses on the attitude of the technology users by relating it to the ease of applying the technology. This study uses several independent variables such as knowledge, trust, comfort, risk, and culture, which is a novelty. The exogenous variables above are the determining variables that affect customer interest in using mobile banking.

The studies in related literature prove that the effect of knowledge on attitudes, convenience, and intentions is positive and significant. Meanwhile, the findings of previous researchers for the effect of trust on attitudes, convenience, usefulness, and intentions are positive and significant. Convenience is one of the determinants of attitudes, convenience, usability, and customer intentions in using mobile banking. Another determinant of attitude is a risk. Meanwhile, risk has a negative and significant effect on convenience, usefulness, and intention. Attitude is a contributing factor to customer intentions in the adoption of $\mathrm{m}$ banking findings. The convenience and usability variables have a positive and significant effect on the intention to use mobile banking. This finding proves that attitude has a positive and significant effect on the intention. Previous research has not explicitly found the influence of culture either directly or indirectly on customer intentions in using mobile banking. In this study, the cultural variable is a novelty variable that acts as an exogenous (free) variable that directly affects the intention (intention) to use mobile services. Banking in Jambi and culture directly affect intentions through attitudes, convenience, and usefulness regarding mobile banking in Jambi.

A research framework consists of variable constructs, namely knowledge, trust, enjoyment, risk, culture, attitude, perceived ease of use, perceived usefulness, and behavior intention, are formulated as follows;



Figure 1: Research Framework 


\section{Hypothesis Development}

Sumarwan (2017) stated that consumer knowledge affects purchasing decisions. Furthermore, Siyal et al. (2019) showed that initial trust is the core barrier to adopting and using m-banking. In this regard, users that feel happy (enjoy) using Internet-based learning have a positive attitude. According to Lou et al. (2005), users that feel Instant Messenger is enjoyable are more likely to use it. In line with this, Pikkarainen et al. (2004) found that Perception of Enjoyment significantly influences intention. Rose et al. (2006) showed that perceived risk affects user attitudes and opinions about perceived usefulness. Additionally, concerning national culture, Mortimer et al. (2015) showed the impact of critical antecedents on adopting m-banking. Based on these findings, the following hypothesis is formulated:

\section{$\mathrm{H}_{1}$ : Knowledge, trust, enjoyment, risk, and culture affect attitudes to use mobile banking services in Jambi}

Clear information facilitates purchasing decisions. Pavlou (2003) found that trust influences perceived usefulness and Perceived Ease of Use of online transactions. Furthermore, enjoyment affects perceived enjoyment and usefulness. Regarding national culture, Mortimer et al. (2015) showed the impact of critical antecedents on adopting m-banking. Based on these findings, the following hypothesis is formulated:

$\mathrm{H}_{2}$ : Knowledge, trust, enjoyment, risk, and culture affect the enjoyment of using mobile banking services in Jambi.

Park et al. (2008) stated that consumers with high knowledge consider product perceived usefulness high. Trust reduces the perception of risk, usefulness, ease of use, and intention to transact. Furthermore, Siyal et al. (2019) showed that lack of awareness, initial trust and compatibility, and perceived risk are the core barriers to M-banking adoption and use in Pakistan. According to Goularte et al. (2018), the cultural dimension does not significantly affect the use of m-banking. Based on these findings, the following hypothesis is formulated:

$\mathrm{H}_{3}$ : Knowledge, trust, enjoyment, risk, and culture affect the perceived usefulness of mobile banking services in Jambi

Consumer knowledge affects intentions to buy a product (Roslina, 2009). In this regard, lack of trust is often why a customer does not use mobile banking (Kim et al., 2009). Moreover, perception of enjoyment significantly influences intention. According to Teo \& Liu (2007), perceived risk negatively and significantly affects attitudes to transact online. In contrast, Goularte et al. (2019) showed that the cultural dimension does not significantly affect the use of mobile banking. Park et al. (2009) showed that PEOU directly influences Behavioral Intention to use I.T. Therefore, most studies highly emphasize P.U. when examining the factors leading to adoption (Park et al., 2009). Based on these findings, the following hypothesis is formulated:

$\mathrm{H}_{4}$ : Knowledge, trust, enjoyment, risk, culture, attitude, perceived ease of use, and perceived usefulness affect the intention to use mobile banking services in Jambi. Jun \& Palacios (2016) found that customer knowledge is a crucial dimension of Behavioral Intention to use m-banking. Moreover, Siyal et al. (2019) stated that initial trust is a core barrier to adoption and the use of m-banking. According to Farah et al. (2018), Perceived Enjoyment significantly affects the intention to adopt m-banking. Mortimer et al. (2015) found that perceived risk (P.R.) is a significant determinant of mobile banking adoption for Australian and Thai consumers. Additionally, Chen et al. (2007) stated that P.R. is a significant barrier to online banking adoption. Based on these findings, the following hypothesis is formulated:

$\mathrm{H}_{5}$ : Knowledge, trust, enjoyment, risk, and culture affect intentions through attitudes to using mobile banking services in Jambi

Siyal et al. (2019) showed that PEOU affects P.U., attitude, and Behavioral Intention of m-banking. In line with this, Deb et al. (2017) found that PEOU and Perceived PU are determinants of Behavioral Intention to adopt m-banking. Furthermore, Jun et al. (2016) found that perceived ease of use significantly influences customer satisfaction or dissatisfaction. According to Mortimer et al. (2015), perceived enjoyment of use is crucial for mobile banking adoption for consumers in Australia. This study empirically proved a positive relationship between perceived usefulness, ease of use, and positive attitudes towards m-banking. Furthermore, Chen et al. (2007) found that two technological aspects of the interface, PEOU, and P.U., significantly influence the customer's adoption intention. Based on these findings, the following hypothesis is formulated:

H6: Knowledge, trust, enjoyment, risk, and culture affect intentions through the Perceived Ease of Use of mobile banking services in Jambi

Park et al. (2008) stated that consumers with high knowledge often focus on product Perceived usefulness. In this regard, Siyal et al. (2019) showed that initial trust is the core barrier to adopting and using m-banking. According to Jamshidi et al. (2018), customer intention to use m-banking with hedonistic and utilitarian features positively influences the flow experience. This means that users who feel happy using Internet-based learning have a positive attitude. Moreover, Rose et al. (2006) showed that P.R. influences user attitudes and opinions about perceived usefulness. According to Mortimer et al. (2015), perceived ease of use, P.U., and P.R. are the main determinants of mobile banking adoption for Australian consumers. Based on these findings, the following hypothesis is formulated:

$\mathrm{H}_{7}$ : Knowledge, trust, enjoyment, risk, and culture affect Behavioral Intention to use mobile banking services in Jambi. 


\section{Research Method}

This study used primary and secondary data collected by administering questionnaires to respondents. This study population comprised mobile banking users at government banks active in 2020 in Jambi Province. A sample of bank customers that use mobile banking application facilities was selected using a proportionate stratified random sampling technique. The path analysis model was used to analyze the relationships and determine the effect of independent variables on the dependent variable. Moreover, the t-test is the partial correlation coefficient test used to prove the effectiveness of the independent variables on the dependent variable. The Ftest was then performed to determine whether the independent variables explain the dependent variable simultaneously. A significant indirect effect of variable $\mathrm{x}$ on $\mathrm{y}$ through the intervening variable was determined using the Sobel test.

\section{Population and Sample}

\section{Population}

The population in this study were mobile banking users at government banks. They were active until September 2020 in Jambi Province, amounting to 103,853 people spread over four cities and regencies in Jambi Province, which consisted of Jambi City, Muara Jambi Regency, Tanjab Regency East, Kerinci Regency/River Full.

\section{Sample}

Sampling in this study using a proportionate stratified random sampling technique. The sample is part of the number and characteristics possessed by the population. In this study, the sample members are bank customers who use mobile banking application facilities spread across four cities and regencies. The number of samples is as many as 400 respondents. The sampling technique was accidental sampling using proportionate stratified random sampling. Proportionate stratified random sampling is used when the population has members/elements that are not homogeneous and proportionally stratified.

\section{Result and Discussion}

The research result shows are presented in table 1.

Table 1: Findings Summary table

\begin{tabular}{|c|c|c|c|c|c|}
\hline$\rho_{x 16}$ & $=0,002($ sig $)$ & $\rho_{x 26}$ & $=0,199($ tdk $)$ & $\rho_{x 36}$ & $=0,000($ sig $)$ \\
\hline$\rho_{x 17}$ & $=0,278($ tdk $)$ & $\rho_{x 27}$ & $=0,688($ tdk $)$ & $\rho_{x 37}$ & $=0,021($ sig $)$ \\
\hline$\rho_{x 18}$ & $=0,069(t d)$ & $\rho_{x 28}$ & $=0,423(t d k)$ & $\rho \times 38$ & $=0,009($ sig $)$ \\
\hline$\rho_{x 46}$ & $=0,000($ sig $)$ & $\rho_{\times 56}$ & $=0,368(\mathrm{tdk})$ & $\rho_{\mathrm{y} 1 \Omega \mathrm{x} 6}$ & $=-2,667(\mathrm{sig})$ \\
\hline$\rho_{x 47}$ & $=0,542($ tdk $)$ & $\rho_{\times 57}$ & $=0,000(\mathrm{sig})$ & $\rho_{\mathrm{y} 1 \Omega \times 7}$ & $=1,165(\mathrm{tdk})$ \\
\hline$\rho_{x 48}$ & $=0,448($ sig $)$ & $\rho_{\times 58}$ & $=0,019(\mathrm{sig})$ & $\rho_{\mathrm{y} 1 \Omega \mathrm{x} 8}$ & $=2,007(\mathrm{sig})$ \\
\hline$\rho_{\mathrm{y} 2 \Omega \mathrm{x} 6}$ & $=1,066($ tdk $)$ & $\rho_{\mathrm{y} 3 \Omega \mathrm{x} 6}$ & $=3,076($ sig $)$ & $\rho_{\mathrm{y} 4 \Omega \mathrm{x} 6}$ & $=-2,861(\mathrm{sig})$ \\
\hline$\rho_{\mathrm{y} 2 \Omega \times 7}$ & $=-\mathbf{0 , 3 8 9}(\mathrm{tdk})$ & $\rho_{\mathrm{y} 3 \Omega \times 7}$ & $=1,918(\mathrm{tdk})$ & $\rho_{\mathrm{y} 4 \Omega \times 7}$ & $=-0,585(\mathrm{tdk})$ \\
\hline$\rho_{\mathrm{y} 2 \Omega \mathrm{x} 8}$ & $=-0,819(t d k)$ & $\rho_{\mathrm{y} 3 \Omega \times 8}$ & $=2,455(\mathrm{sig})$ & $\rho_{\mathrm{y} 4 \Omega \mathrm{x} 8}$ & $=-0,792(\mathrm{tdk})$ \\
\hline$\rho_{y 5 \Omega \times 6}$ & $=0,753(t d k)$ & $\rho \mathrm{e}_{1}$ & $=0,957$ & $\rho_{\mathrm{y} 1}$ & $=0,000(\mathrm{sig})$ \\
\hline$\rho_{\mathrm{y} 5 \Omega \times 7}$ & $=3,002($ sig $)$ & $\rho \mathrm{e}_{2}$ & $=0,884$ & $\rho_{\mathrm{y} 2}$ & $=0,053(\mathrm{tdk})$ \\
\hline \multirow[t]{6}{*}{$\rho_{y 5 \Omega \times 8}$} & $=2,241(\mathrm{sig})$ & $\rho e_{3}$ & $=0,931$ & $\rho_{\mathrm{y} 3}$ & $=0,008(\mathrm{sig})$ \\
\hline & & $\rho \mathrm{e}_{4}$ & $=0,772$ & $\rho_{\mathrm{y} 4}$ & $=0,008(\mathrm{sig})$ \\
\hline & & & & $\rho_{y 5}$ & $=0,009(\mathrm{sig})$ \\
\hline & & & & $\rho_{\mathrm{y} 6}$ & $=0,000(\mathrm{sig})$ \\
\hline & & & & $\rho_{\mathrm{y} 7}$ & $=0,001(\mathrm{sig})$ \\
\hline & & & & $\rho_{\mathrm{y} 8}$ & $=0,000(\mathrm{sig})$ \\
\hline
\end{tabular}

This study examines the direct and indirect effect of knowledge, trust, enjoyment, risk, and culture on attitude, the Perceived Ease of Use, Perceived Usefulness, and the intent to use mobile service banking in Jambi. The following discussion as bellow explained;

The hypothesis test results showed that knowledge significantly and negatively affects customer attitudes toward Jambi mobile banking services. This study narrows the existing gap and supports Bang et al. (2000), which found that consumers' knowledge is indirectly related to their attitudes. However, the results widen the existing gap and contradict Munir et al. (2013), which found a positive and significant effect of knowledge on attitudes and intentions to use mobile banking services. Furthermore, this study does not support Munir et al. (2013), which found a positive and significant effect of trust on customer attitudes towards mobile banking services. Trust does not affect the customers' attitude to use mobile service banking in Jambi, contradicting Laforet \& Li, 2005).

Enjoyment positively and significantly affects customer attitudes towards mobile banking services in Jambi. These results narrow the existing gap and support Munir et al. (2013), which found that enjoyment perception positively and significantly affects attitudes. 
Moreover, this finding is consistent with Dabholkar \& Bagozi (2002), which found that enjoyment significantly affects attitudes. The risk significantly and negatively affect customers' attitudes towards mobile service banking in Jambi. These findings narrow the existing gap and support Laforet \& Li (2005) and Teo \& Liu (2007), which showed a significant negative effect of perceived risk on attitudes towards online transactions. However, this study contradicts Munir et al. (2013), which found that risk perception does not significantly influence customer attitudes towards mobile banking services.

Culture does not directly influence the customers' attitudes to use mobile service banking in Jambi. Anil \& Neelika (2017) showed that openness to change significantly affects adoption and has no impact on the reasons and attitudes towards m-banking. These findings support Sumarwan (2017), which found that products and services significantly influence culture because they carry cultural meaning.

The hypothesis test results showed that knowledge does not directly influence the Perceived Ease of Use of customers to use mobile banking services in Jambi. These results support Debbianita \& Sitorus (2016), which found that the UMKM actors' knowledge concerning Sak Etap does not affect the Perceived Ease of Use of access to financial institutions. However, these findings contradict Munir et al. (2013), which found a positive and significant effect of knowledge on Perceived Ease of Use. This means that knowledge about information technology affects the Perceived Ease of Use.

Trust does not directly influence the Perceived Ease of Use of customers to use mobile service banking in Jambi. These results contradict Siyal et al. (2019), which found that trust positively and significantly affects the Perceived Ease of Use. Similarly, Munir et al. (2013) showed that trust significantly and positively affects the Perceived Ease of Use. Trust and increased customer confidence improve the attitudes towards mobile banking services. Furthermore, enjoyment positively and significantly affects customers' Perceived Ease of Use to use mobile banking services in Jambi. These results support Munir et al. (2013), which found that enjoyment perception positively and significantly influences the Perceived Ease of Use. Additionally, these results are consistent with Sun \& Zhang (2006), which found that enjoyment significantly affects behavioral intentions to use information technology through perceived ease of use (PEOU).

Risk positively and significantly affects customers' Perceived Ease of Use to use mobile service banking in Jambi. These findings support Siyal et al. (2019), which found that perceived risk positively and significantly affects use enjoyment. However, these results contradict Munir et al. (2013), which found a negative and significant effect of risk perception regarding mobile banking on Perceived Ease of Use. Culture positively and significantly affects customers' Perceived Ease of Use to use mobile service banking in Jambi. This result aligns with Dwiastuti et al. (2012), which stated that trust, values, and habits direct a person to use an item or service. Trust, values, and customs arise when people interact, relate, and mutually influence behavior. In line with this, Anil \& Neelika (2017) stated that values positively and significantly influence adoption and attitudes.

The hypothesis test results showed no direct influence of knowledge on perceived usefulness. These results support Munir et al. (2013), which found that knowledge does not significantly affect Perceived Usefulness in mobile banking. However, they contradict Park \& Kim (2008), which stated that consumers with high knowledge consider product Perceived usefulness high.

Trust does not directly affect Perceived Usefulness. These results contradict Siyal et al. (2019), which stated that trust positively and significantly affects perceived usefulness. Similarly, Munir et al. (2013) stated that trust positively and significantly affects Perceived Usefulness. It means that higher customer trust increases the perceived usefulness of mobile banking services. Enjoyment positively and significantly affects the perceived usefulness of customers to use mobile banking services in Jambi. This study supports Munir et al. (2013), which found a positive and significant influence of enjoyment on Perceived Usefulness. Also, these results are consistent with Deb \& Agrawal (2017) and Sun \& Zhang (2006).

There is no direct effect of risk on Perceived Usefulness. These results contradict Siyal et al. (2019), which stated that risk positively and significantly affects perceived usefulness. Additionally, these findings contradict Rose \& Fogarty (2006) and Munir et al. (2013). Culture positively and significantly impacts the Perceived Usefulness of customers to use mobile service banking in Jambi. These findings contradict Goularte, \& Zilber (2019), and Baptista \& Oliveira (2015).

The hypothesis test results showed that knowledge positively and significantly affects the behavioral intention of customers to use mobile banking services in Jambi. These results are consistent with Munir et al. (2013), which found a direct and positive influence of knowledge on customers' behavioral intentions to use mobile banking services. Also, these findings are in line with Miniard et al. (2005) and Lin \& Lin (2007). There is no direct effect of trust on the behavioral intention of customers to use mobile service banking in Jambi. These results support Farah et al. (2018), which found that trust does not significantly affect behavioral intention. However, they contradict Kwateng et al. (2019) and Deb et al. (2017). Enjoyment positively and significantly affect the behavioral intention of customers to use mobile banking services in Jambi. These results align with Farah et al. (2018) and Lou et al. (2005), which found that users who perceive Instant Messenger as enjoyable tend to use it. However, this contradicts Sun et al. (2006), which showed that enjoyment has no significant effect on behavioral intention.

The risk significantly and negatively affects customers' behavioral intention to use mobile banking services in Jambi. These results align with Mortimer et al. (2015) and Munir et al. (2013), which found that perceived risk negatively and significantly influences the intention to use mobile banking. However, this contradicts Farah et al. (2018), which found that risk had no significant effect on behavioral intention. Furthermore, culture positively and significantly impacts customers' behavioral intention to use mobile banking 
services in Jambi. These findings align with Tam (2017) and Anil \& Neelika (2017), which found that cultural trust affects mobile banking users. Additionally, the findings confirm that openness to change significantly influences the reasons for adoption.

Attitude positively and significantly affects customers' behavioral intention to use mobile banking services in Jambi. These results support Siyal et al. (2019), which found that attitude positively and significantly influences behavioral intention. Also, this is in line with Anil \& Neelika (2017), Deb et al. (2014), and Munir et al. (2013), which found a significant influence of attitude on the intention to use mobile banking services. Perceived Ease of Use positively and significantly affect customers' behavioral intention to use mobile banking services in Jambi. These results are consistent with Mortimer et al. (2015), Deb et al. (2014), and Munir et al. (2013), which found that Perceived Ease of Use positively and significantly affects intentions to use mobile banking services. However, this contradicts Sharma et al. (2017) and Jun et al. (2016), which found that enjoyment influences satisfaction or dissatisfaction in using m-banking.

Perceived usefulness positively and significantly affects customers' behavioral intention to use mobile banking services in Jambi. These results support Siyal et al. (2019), which found that Perceived Usefulness positively and significantly influences the intention to use mobile banking. Additionally, this is in line with Munir et al. (2013), Deb et al. (2017), and Sharma et al. (2017), which found that utility (P.U.) positively influences mobile banking adoption.

The hypothesis test results showed that knowledge negatively and significantly affects behavioral intention through customer attitudes to use mobile banking services in Jambi. These are consistent with Munir et al. (2013), which found that knowledge significantly, positively, and indirectly affects behavioral intention through the attitude towards mobile banking services. Moreover, there is no indirect influence of trust on behavioral intention through attitude. These results contradict Munir et al. (2013), which found that trust has a significant indirect positive effect on Intention through Attitude. Therefore, with greater customer trust, the indirect effect of enjoyment on behavioral intention through attitude is significant and positive. These results support Munir et al. (2013), which found that enjoyment has a significant indirect positive effect on Intention through Attitude.

Risk negatively and significantly affects behavioral intention through attitude. These results support Munir et al. (2013), which found that risk has a significant, indirect negative effect on Intention through Attitude. However, there is no indirect influence of culture on behavioral intention through attitude. The results show that increased or decreased enjoyment in cultural variables through attitudes does not influence customers' behavioral intention to use mobile banking services in Jambi.

The hypothesis test results showed no indirect effect of knowledge on behavioral intention through the Perceived Ease of Use of customers to use mobile banking services in Jambi. These results contradict Munir et al. (2013), which found that knowledge has a positive and significant indirect effect on intentions through Perceived Ease of Use. Furthermore, there is no indirect effect of trust on behavioral intention through Perceived Ease of Use. These findings are not in line with Munir et al. (2013), which found that trust has a positive and significant indirect effect on intentions through Perceived Ease of Use. There is no indirect effect of enjoyment on behavioral intention through Perceived Ease of Use. These results are consistent with Munir et al. (2013), which showed that enjoyment does not indirectly affect intentions through Perceived Ease of Use.

There is no indirect effect of risk on behavioral intention through Perceived Ease of Use. These results contradict Munir et al. (2013), which found that risk has a negative and significant indirect effect on intentions through Perceived Ease of Use. Moreover, culture positively and significantly influences behavioral intention through Perceived Ease of Use. The research results show that any Perceived Ease of Use in cultural variables through enjoyment does not affect the customer's behavioral intention to use mobile banking services in Jambi.

Based on the hypothesis testing results, the indirect effect of knowledge on behavioral intention through Perceived Usefulness is significant and positive. These results are not in line with Munir et al. (2013), which found that knowledge has a negative and significant indirect effect on intentions through perceived usefulness. Furthermore, there is no indirect effect of trust on behavioral intention through perceived usefulness. This contradicts Munir et al. (2013), which found that trust positively and significantly indirectly affect intentions through perceived usefulness.

Enjoyment has an indirect significant positive effect on behavioral intention through Perceived Usefulness. These results are inconsistent with Munir et al. (2013), which found that enjoyment does not indirectly affect intentions through perceived usefulness. Moreover, there is no indirect effect of risk on behavioral intention through perceived usefulness. On the other hand, Munir et al. (2013) contradicted which found that risk has a negative and significant indirect effect on intentions through Perceived Usefulness. Culture has an indirect significant favorable influence on behavioral intention through Perceived Usefulness. The result shows that enjoyment in cultural variables through Perceived Usefulness does not affect intention.

The model in Figure 2 was created based on these findings: 


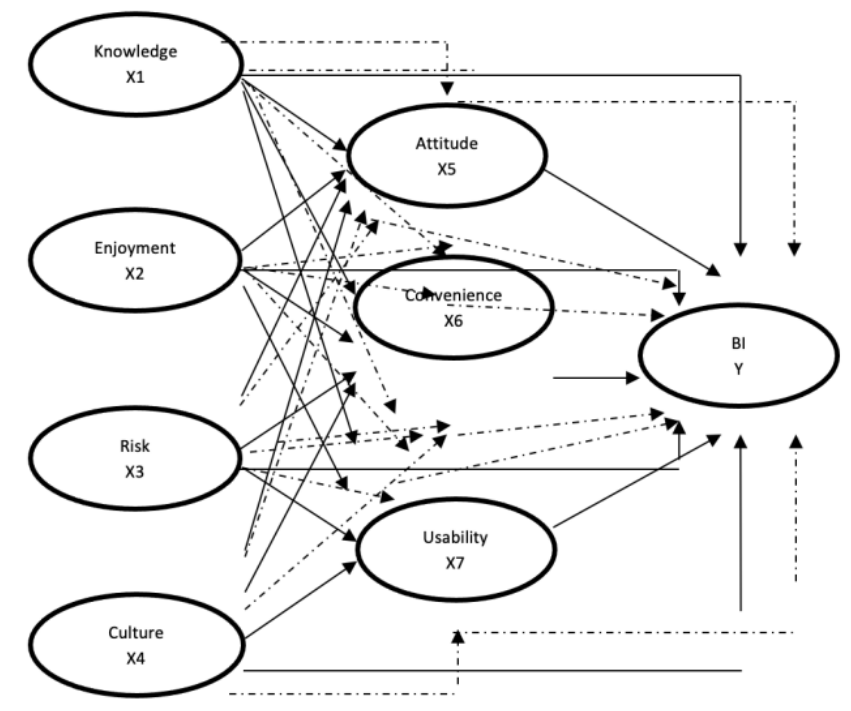

Figure 2: Study Findings Model

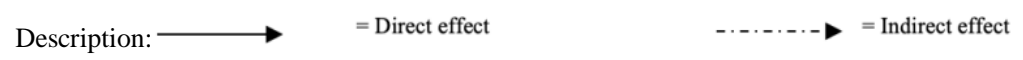

\section{Conclusions}

Knowledge, enjoyment, and risk are direct determinants of customer attitudes towards using mobile banking in Jambi, while trust and culture are not. Trust, knowledge, and risk do not directly support Perceived Ease of Use. However, enjoyment and culture support the use of m-banking in Jambi. Knowledge, trust, and risk do not contribute to the perceived usefulness of customers in using mobile banking in Jambi. In contrast, enjoyment and culture directly contribute to customer-perceived usefulness in mobile banking services. Enjoyment, knowledge, risk, culture, attitude, Perceived Ease of Use, and Perceived Usefulness significantly influence customer Behavioral Intention to use mobile banking services in Jambi, but not trust. Risk, enjoyment, and knowledge indirectly influence Behavioral Intention through customer attitudes to mobile banking services in Jambi, while trust and culture do not. Culture supports Behavioral Intention through customer Perceived Ease of Use for mobile banking services in Jambi, while knowledge, trust, enjoyment, and risk do not. Knowledge, enjoyment, and culture indirectly influence Behavioral Intention through the perceived usefulness of customers for mobile banking services in Jambi, while trust and risk do not.

Future studies should further explore the indicators for the trust variable from the literature review and previous studies to narrow the gap in their influence on Behavioral Intention using mobile banking. The sample in future studies should comprise more millennial generation because it constitutes the largest workforce today. The generation grew up when information technology was pioneered, developed, and became a part of everyday life, familiarizing it with gadgets. Future management should focus on customer enjoyment and trust in mobile banking. Customers must reap the benefits of mobile banking facilities for them to embrace and conduct online transactions. Additionally, the reliability of their banking facility must constantly be updated.

\section{References}

Ajzen, I., \& Fishbein, M. (1975). A Bayesian analysis of attribution processes. Psychological Bulletin, 82(2), 261. https://doi.org/10.1037/h0076477

Bang, H.-K., Ellinger, A. E., Hadjimarcou, J., \& Traichal, P. A. (2000). Consumer concern, knowledge, belief, and attitude toward renewable energy: An application of the reasoned action theory. Psychology and Marketing, 17(6), 449-468. https://doi.org/10.1002/(sici)1520-6793(200006)17:6<449::aid-mar2>3.0.co;2-8

Baptista, G., \& Oliveira, T. (2015). Understanding mobile banking: The unified theory of acceptance and use of technology combined with cultural moderators. Computers in Human Behavior, 50, 418-430. https://doi.org/10.1016/j.chb.2015.04.024

Bruner II, G. C., \& Kumar, A. (2005). Explaining consumer acceptance of handheld Internet devices. Journal of Business Research, 58(5), 553-558. https://doi.org/10.1016/j.jbusres.2003.08.002

Dabholkar, P.A., Bagozzi, R.P. An attitudinal model of technology-based self-service: Moderating effects of consumer traits and situational factors. J. of the Acad. Mark. Sci. 30, 184 (2002). https://doi.org/10.1177/0092070302303001

Davis, F. D., Bagozzi, R. P., \& Warshaw, P. R. (1989). User acceptance of computer technology: a comparison of two theoretical models. Management Science, 35(8), 982-1003. https://doi.org/10.1287/mnsc.35.8.982

Deb, M. and Agrawal, A. (2017). Factors impacting the adoption of m-banking: understanding brand India's potential for financial inclusion, Journal of Asia Business Studies, Vol. 11 No. 1, pp. 22-40. https://doi.org/10.1108/JABS-11-2015-0191 
Debbianita, D., \& Sitorus, D. N. (2016). Analisis Determinan Tingkat Pengetahuan Pelaku UMKM mengenai SAK ETAP serta Pengaruhnya terhadap Kemudahan Akses ke Lembaga Keuangan. Jurnal Akuntansi, 8(1), 86-104. http://dx.doi.org/10.32493/JABI.v3i1.y2020.p96-116

Dwiastuti, R., Shinta, A., \& Isaskar, R. (2012). Ilmu perilaku konsumen. Perpustakaan Nasional Katalog Terbitan (PNKT) UB Press, Malang.

Farah, M.F., Hasni, M.J.S. and Abbas, A.K. (2018). Mobile-banking adoption: empirical evidence from the banking sector in Pakistan, International Journal of Bank Marketing, Vol. 36 No. 7, pp. 1386-1413. https://doi.org/10.1108/IJBM-10-20170215

Gupta, A. and Arora, N. (2017).Consumer adoption of m-banking: a behavioral reasoning theory perspective, International Journal of Bank Marketing, 35 (4), 733-747. https://doi.org/10.1108/IJBM-11-2016-0162

Goularte, A.d.C. and Zilber, S.N. (2020), The moderating role of cultural factors in the adoption of mobile banking in Brazil", International Journal of Innovation Science, 11(1), 63-81. https://doi.org/10.1108/IJIS-11-2017-0119

Hacioglu, U., \& Sevgilioglu, G. (2019). The evolving role of automated systems and its cyber-security issue for global business operations in Industry 4.0. International Journal of Business Ecosystem \& Strategy (2687-2293), 1(1), 01-11. https://doi.org/10.36096/ijbes.v1i1.105

Jamshidi, D., Keshavarz, Y., Kazemi, F. and Mohammadian, M. (2018), Mobile banking behavior and flow experience: An integration of utilitarian features, hedonic features and trust, International Journal of Social Economics, 45(1) 57-81. https://doi.org/10.1108/IJSE-10-2016-0283

Jun, M. and Palacios, S. (2016), Examining the key dimensions of mobile banking service quality: an exploratory study", International Journal of Bank Marketing, 34(3), 307-326. https://doi.org/10.1108/IJBM-01-2015-0015

Karjaluoto, H., Jayawardhena, C., Kuckertz, A., \& Kautonen, T. (2008). 10. Sources of trust in permission-based mobile marketing: a cross-country comparison. Trust and new technologies: Marketing and management on the internet and mobile media, 165.

Kim, G., Shin, B., \& Lee, H. G. (2009). Understanding dynamics between initial trust and usage intentions of mobile banking. Information Systems Journal, 19(3), 283-311. https://doi.org/10.1111/j.1365-2575.2007.00269.x

Laforet, S. and Li, X. (2005), Consumers' attitudes towards online and mobile banking in China, International Journal of Bank Marketing, 23(5), 362-380. https://doi.org/10.1108/02652320510629250

Lee, M.K.O., Cheung, C.M.K., Lim, K.H. and Ling Sia, C. (2006), Understanding customer knowledge sharing in web-based discussion boards: An exploratory study, Internet Research, 16(3), 289-303. https://doi.org/10.1108/10662240610673709

Li, Y. H., \& Huang, J. W. (2009). Applying theory of perceived risk and technology acceptance model in the online shopping channel. World Academy of Science, Engineering and Technology, 53(1), 919-925.

Lin, N. H., \& Lin, B. S. (2007). The effect of brand image and product knowledge on purchase intention moderated by price discount. Journal of International Management Studies, 2(2), 121-132.

Littler, D., \& Melanthiou, D. (2006). Consumer perceptions of risk and uncertainty and the implications for behavior towards innovative retail services: the case of internet banking. Journal of Retailing and Consumer Services, 13(6), 431-443. https://doi.org/10.1016/j.jretconser.2006.02.006

Lou, Hao; Chau, Patrick Y.K.; and Li, Dahui (2005).Understanding Individual Adoption of Instant Messaging: An Empirical Investigation, Journal of the Association for Information Systems, 6(4), https://doi.org/10.17705/1jais.00066

Mauro C. Hernandez, J. and Afonso Mazzon, J. (2007), Adoption of internet banking: proposition and implementation of an integrated methodology approach, International Journal of Bank Marketing, Vol. 25 No. 2, pp. 72-88. https://doi.org/10.1108/02652320710728410

Miniard, P. W., Blackwell, R. D., \& Engel, J. F. (2005). How reference groups influence human behavior (Consumer B). SouthWestern College.

Mishra, V., \& Bisht, S. S. (2013). Mobile banking in a developing economy: A customer-centric model for policy formulation. Telecommunications Policy, 37(6-7), 503-514. https://doi.org/10.1016/j.telpol.2012.10.004

Mortimer, G., Neale, L., Hasan, S.F.E. and Dunphy, B. (2015), Investigating the factors influencing the adoption of m-banking: a cross-cultural study, International Journal of Bank Marketing, Vol. 33 No. 4, pp. 545-570. https://doi.org/10.1108/IJBM-072014-0100

Mowen, J. C., \& Minor, M. (2002). Perilaku konsumen. jakarta: erlangga.

Munir, A. R., Idrus, M. S., Kadir, R. A., \& Jusni, S. E. (2013). Acceptance of mobile banking services in Makassar: a technology acceptance model (TAM) approach. OSR Journal of Business and Management, 7(6), 52-59. https://doi.org/ 10.9790/487X0765259

Owusu Kwateng, K., Osei Atiemo, K.A. and Appiah, C. (2019), Acceptance and use of mobile banking: an application of UTAUT2, Journal of Enterprise Information Management, 32(1), 118-151. https://doi.org/10.1108/JEIM-03-2018-0055

Park, D. H., \& Kim, S. (2008). The effects of consumer knowledge on message processing of electronic word-of-mouth via online consumer reviews. Electronic Commerce Research and Applications, 7(4), 399-410. https://doi.org/10.1016/j.elerap.2007.12.001

Park, N., Roman, R., Lee, S., \& Chung, J. E. (2009). User acceptance of a digital library system in developing countries: An application of the Technology Acceptance Model. International Journal of Information Management, 29(3), 196-209. https://doi.org/10.1016/j.ijinfomgt.2008.07.001 
Pavlou, P. A. (2003). Consumer acceptance of electronic commerce: Integrating trust and risk with the technology acceptance model. International Journal of Electronic Commerce, 7(3), 101-134. https://doi.org/10.1080/10864415.2003.11044275

Pikkarainen, T., Pikkarainen, K., Karjaluoto, H. and Pahnila, S. (2004), Consumer acceptance of online banking: an extension of the technology acceptance model, Internet Research, 14(3), 224-235. https://doi.org/10.1108/10662240410542652

Rose, J., \& Fogarty, G. J. (2006). Determinants of perceived usefulness and ease of use in the technology acceptance model: senior consumers' adoption of self-service banking technologies. Business Across Borders in the 21st Century (Vol. 2, pp. 122-129). http://eprints.usq.edu.au/id/eprint/1649

Roslina, R. (2009). Pengaruh Pengetahuan Produk dan Citra Merek Terhadap Pembelian Produk. Jurnal Bisnis \& Manajemen, 10(2).

Sahoo, D. and S. Pillai, S. (2017), Role of mobile banking servicescape on customer attitude and engagement: An empirical investigation in India, International Journal of Bank Marketing, 35(7), 1115-1132. https://doi.org/10.1108/IJBM-09-20150144

Salo, J. and Karjaluoto, H. (2007). A conceptual model of trust in the online environment, Online Information Review, 31(5) 604621. https://doi.org/10.1108/14684520710832324

Schlosser, A. E., White, T. B., \& Lloyd, S. M. (2006). Converting web site visitors into buyers: how web site investment increases consumer trust and online purchase intentions. Journal of Marketing, 70(2), 133-148. https://doi.org/10.1509/jmkg.70.2.133

Shaikh, A. A., \& Karjaluoto, H. (2015a). Mobile banking adoption: A literature review. Telematics and Informatics, 32(1), $129-142$. https://doi.org/10.1016/j.tele.2014.05.003

Kumar Sharma, S. and Madhumohan Govindaluri, S. (2014), Internet banking adoption in India: Structural equation modeling approach, Journal of Indian Business Research, 6(2), 155-169. https://doi.org/10.1108/JIBR-02-2013-0013

Siyal, A.W., Ding, D. and Siyal, S. (2019), M-banking barriers in Pakistan: A customer perspective of adoption and continuity intention, Data Technologies and Applications, 53(1), 58-84. https://doi.org/10.1108/DTA-04-2018-0022

Sun, Heshan and Zhang, Ping (2006). Causal Relationships between Perceived Enjoyment and Perceived Ease of Use: An Alternative Approach, Journal of the Association for Information Systems: $7(1)$ Available at: http://aisel.aisnet.org/jais/vol7/iss1/24

Sumarwan, U. (2011). Perilaku konsumen: Teori dan penerapannya dalam pemasaran. Bogor: Ghalia Indonesia.

Sun, Heshan and Zhang, Ping (2006). Causal Relationships between Perceived Enjoyment and Perceived Ease of Use: An Alternative Approach, Journal of the Association for Information Systems: 7(1) Available at: http://aisel.aisnet.org/jais/vol7/iss1/24

Sun, Heshan and Zhang, Ping (2006). Causal Relationships between Perceived Enjoyment and Perceived Ease of Use: An Alternative Approach, Journal of the Association for Information Systems: $7(1)$ Available at: http://aisel.aisnet.org/jais/vol7/iss 1/24

Teo, T. S., \& Liu, J. (2007). Consumer trust in e-commerce in the United States, Singapore, and China. Omega, 35(1), 22-38, https://doi.org/10.1016/j.omega.2005.02.001

Yudiarti, R. F. E., \& Puspaningrum, A. (2018). The Role Of Trust As A Mediation Between The Effect Of Perceived Usefulness And Perceived Ease Of Use To Interest To Buy E-Book. Jurnal Aplikasi Manajemen, 16(3), 494-502. http://dx.doi.org/ 10.21776/ub.jam.2018.016.03.14

Publisher's Note: SSBFNET stays neutral with regard to jurisdictional claims in published maps and institutional affiliations.

\section{(c) (1)}

(C) 2021 by the authors. Licensee SSBFNET, Istanbul, Turkey. This article is an open access article distributed under the terms and conditions of the Creative Commons Attribution (CC BY) license (http://creativecommons.org/licenses/by/4.0/).

International Journal of Research in Business and Social Science (2147-4478) by SSBFNET is licensed under a Creative Commons Attribution 4.0 International License. 